\title{
A Hematopoietic Perspective on the Promiscuity and Specificity of $\mathbf{G} \alpha_{16}$ Signaling
}

\author{
Yan Su Maurice K.C. Ho Yung H. Wong \\ Biotechnology Research Institute, Molecular Neuroscience Center, and Department of Biochemistry, \\ Hong Kong University of Science and Technology, Hong Kong, SAR, China
}

\section{Key Words}

G-protein-coupled receptor $\cdot \mathrm{G}_{16} \cdot$ Hematopoietic cells • Kinase $\cdot$ Signaling $\cdot$ Transcription

\begin{abstract}
$G \alpha_{16}$, a member of $G_{q}$ subfamily, is expressed exclusively in hematopoietic cells, and its expression is highly modulated during lineage differentiation. Although functional redundancy within $G_{q}$ subclass members has been observed in many established models, $G \alpha_{16}$ possesses unique structural and biochemical properties not shared by other family members. Its broad receptor-coupling capacity and unique downstream binding partners and effectors allow the occurrence of both inositol lipid-dependent and -independent signals. Apart from its recognized biological functions in hematopoietic cell responses, the enlistment of complicated signaling pathways further signifies the importance of $G \alpha_{16}$ in signal integration. This review aims to provide an updated appreciation and rational discussion of $G \alpha_{16}$ signaling with regard to its promiscuity and specificity.
\end{abstract}

Copyright $\odot 2009$ S. Karger AG, Basel

\section{Introduction}

Heterotrimeric $G$ proteins are divided into four subfamilies $\left(G_{s}, G_{i}, G_{q}\right.$, and $\left.G_{12}\right)$ based on the sequences and functional similarities of their $G \alpha$ subunits. $G \alpha_{16}$ is a member of the $\mathrm{G} \alpha_{\mathrm{q}}$ subfamily with molecular weight of $43.5 \mathrm{kDa}$ [1]. Protein expression of $\mathrm{G \alpha}_{16}$ is confined exclusively to normal and malignant hematopoietic cells [1, 2]. The murine homolog $\mathrm{G} \alpha_{15}$ can also be detected in tissues such as spleen, thymus, lung and bone marrow where hematopoietic cells reside. $\mathrm{G} \alpha_{16}$ shows $40 \%$ amino acid identity with $\mathrm{G} \alpha_{\mathrm{s}}, 45 \%$ with $\mathrm{G} \alpha_{\mathrm{i}}$, and $57 \%$ with $\mathrm{G} \alpha_{11}$ and $\mathrm{G} \alpha_{\mathrm{q}}[1,3]$. Like the other members in the $\mathrm{G}_{\mathrm{q}}$ subfamily, $\mathrm{G} \alpha_{16}$ lacks a cysteine residue four amino acids from the carboxyl terminus and is not a substrate for pertussis toxin (PTX)-mediated ADP-ribosylation site [1]. Instead of alanine or threonine, it contains a proline at position 50 in region A that is important for GTP binding and endogenous GTPase activity [3]. Based on sequence alignment, $\mathrm{G} \alpha_{16}$ is predicted to have an extraordinarily long $\alpha 4 / \beta 6$ loop which is an important region for both receptor and effector coupling $[1,4,5]$. Furthermore, the $\mathrm{G} \alpha_{16}$ sequence includes a motif with a distinct homology to a hemoregulatory peptide pEEDCK associated with hematopoietic growth control [6]. pEEDCK induces reversible arrest of hematopoietic cells in $\mathrm{G}_{0} / \mathrm{G}_{1}$ phase without inducing differentiation, supporting the notion that $G \alpha_{16}$ may be involved in the maintenance of the immature state of the cells [7].

All heterotrimeric $\mathrm{G}$ proteins are composed of three subunits $G \alpha, G \beta$ and $G \gamma$. Ligand binding to a G-proteincoupled receptor (GPCR) induces the exchange of GDP bound on G $\alpha$ to GTP, and the resulting conformational changes allow both $G \alpha$ and $G \beta \gamma$ to regulate a wide range

Prof. Yung H. Wong

Department of Biochemistry, Hong Kong University of Science and Technology

Clear Water Bay, Kowloon, Hong Kong, SAR (China)

Tel. +852 2358 7328, Fax +852 23581559

E-Mail boyung@ust.hk 


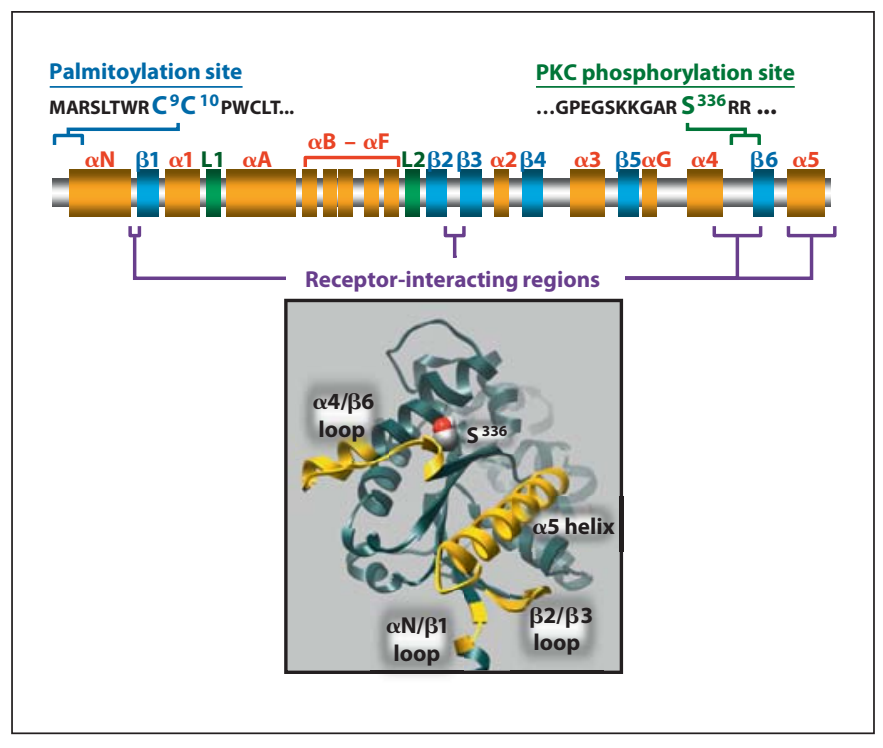

Fig. 1. Covalent modifications and receptor-interacting regions of $\mathrm{G} \alpha_{16}$. A schematic diagram shows the linear arrangement of the secondary structures of $\mathrm{G} \alpha_{16}$. $\alpha$-Helices and $\beta$-strands are colored in orange and blue, respectively. The two green linker regions (L1 and L2) connect the two major tertiary structural domains - helical and GTPase domains - of $\mathrm{G} \alpha_{16}$. The amino acid sequences corresponding to the $\mathrm{N}$-terminus and part of the $\alpha 4 / \beta 6$ loop are shown, with the palmitoylated cysteines and the PKC phosphorylation site indicated in blue and green, respectively. Numbers in superscripts within the sequences correspond to the positions of the modified residues. Four known receptor-interacting regions on $\mathrm{G} \alpha_{16}$ are marked below the schematic structural diagram, and are illustrated in a hypothetical $G \alpha_{16}$ structure. The model was generated by homologous modeling using Swiss-Model [87] and the template structures of $\mathrm{G} \alpha_{\mathrm{i} 1}$ and $\mathrm{G} \alpha_{\mathrm{t} 1}$ in their corresponding trimeric $G$ protein structures $[88,89]$. The view shows the putative receptor-interacting surface on the GTPase domain of $\mathrm{G} \alpha_{16}$, with the four receptor-interacting regions highlighted in yellow. The PKC phosphorylation site on $\alpha 4 / \beta 6$ loop is highlighted by space-filled representation.

of downstream effectors. Following the activation of $\mathrm{G}_{16}$, both $\mathrm{G} \alpha$ and $\mathrm{G} \beta \gamma$ dimer can stimulate at least 3 subtypes of phospholipase C $\beta$ (PLC $\beta 1-3)$ and release inositol trisphosphate $\left(\mathrm{IP}_{3}\right)$ and diacylglycerol as revealed in an exogenous expression system [8]. These second messengers in turn trigger intracellular $\mathrm{Ca}^{2+}$ mobilization and stimulation of protein kinase $\mathrm{C}$ (PKC), and eventually lead to the activation of several transcriptional factors. Emerging data suggest that $G \alpha_{16}$ participates in the activation of transcriptional factors such as signal transducer and activator of transcription 3 (STAT3) and nuclear factor $\kappa \mathrm{B}$ $(\mathrm{NF}-\kappa \mathrm{B})$. It has been demonstrated that C5a-induced phosphoinositide accumulation and $\mathrm{Ca}^{2+}$ release are im- paired in macrophages from $\mathrm{G}_{15}{ }^{-/-}$mice, despite of the normal hematopoiesis in these mice as well as in $\mathrm{G} \alpha_{15}{ }^{-1-}$ $\mathrm{G} \alpha_{\mathrm{q}}{ }^{-/-}$double-knockout and $\mathrm{G} \alpha_{11}{ }^{-/-}$mice, suggesting that there is functional redundancy in $\mathrm{G}_{\mathrm{q}}$ class signaling [9].

$G \alpha_{16}$ is coupled to a wide variety of receptors that are not linked to $G \alpha_{\mathrm{q} / 11}$. The receptor promiscuity of $\mathrm{G} \alpha_{16}$ and its exclusive expression in the hematopoietic system indicate that it has unique functions in hematopoietic cells not performed by other $\mathrm{G}_{\mathrm{q}}$ subfamily members. This review summarizes the divergent biochemical features of $\mathrm{G} \alpha_{16}$, and provides newly appreciated and logical speculations of the biological functions of this $\mathrm{G}$ protein.

\section{Covalent Modifications of $\mathrm{G} \alpha_{16}$}

Like other members of the $G_{\mathrm{q}}$ subfamily, $G \alpha_{16}$ is predicted to be palmitoylated at its $\mathrm{N}$-terminus. Three cysteine residues are located at the $\mathrm{N}$-terminus of $\mathrm{G} \alpha_{16}$, and recent data suggest that $\mathrm{Cys}^{9}$ and $\mathrm{Cys}^{10}$ but not $\mathrm{Cys}^{13}$ are palmitoylated (fig. 1) [10]. Together with the polybasic residues found on the $\mathrm{N}$-terminus of $\mathrm{G} \alpha_{16}$, such modifications are critical for plasma membrane attachment and PLC $\beta$ activation [10]. So far there is no other type of covalent modification detected on the N-terminus of $\mathrm{G} \alpha_{16}$, and it is not known if the palmitoylation of $\mathrm{G}_{16}$ is dynamically regulated [11] or whether there is any heterogeneity of the attached lipid moiety as that in $\mathrm{G \alpha}_{\mathrm{z}}$ [12].

$\mathrm{G} \alpha_{16}$ is subjected to regulation by protein phosphorylation. The coupling of thyrotropin-releasing hormone receptor to $G \alpha_{16}$ in Xenopus oocytes is impaired by the activation of $\mathrm{PKC}$ [13]. Such regulation is unique among the members of the $\mathrm{G}_{\mathrm{q}}$ subfamily. In vitro phosphorylation study shows that $\mathrm{G} \alpha_{16}$ is a direct substrate of PKC, and the phosphorylation site has eventually been identified as $\mathrm{Ser}^{336}$ on the unique long insert of the $\alpha 4 / \beta 6$ loop of $\mathrm{G} \alpha_{16}$ (fig. 1) [14], which is a critical receptor-interacting region as identified in another study [15]. Similar PKC-mediated phosphorylation has been noted with the murine homolog $G \alpha_{15}$ and the phosphorylation site falls in the same region [14]. The constitutive activity of the GTPase-deficient $\left(\mathrm{Q}^{212} \mathrm{~L}\right)$ mutant of $\mathrm{G} \alpha_{16}$ in PLC $\beta$ activation is only weakly affected by the phosphorylation. Residual phosphorylation is observed in the $\mathrm{G}_{16} \mathrm{Ser}^{336} \mathrm{mu}-$ tant but not the quadruple mutant made in an earlier study [13], indicating that PKC might also phosphorylate the other three putative target sites $\left(\mathrm{Ser}^{4}, \mathrm{Thr}^{6}\right.$ and $\mathrm{Ser}^{53}$ ). Since PKC is a major downstream effector of PLC $\beta$, the action of $\mathrm{PKC}$ on $\mathrm{G} \alpha_{16}$ may serve as a negative feedback mechanism to limit the activity of $G \alpha_{16}$. To date, no oth- 
er report shows the interaction of $\mathrm{G} \alpha_{16}$ with other serine/ threonine or tyrosine kinases.

A recent study shows that $\mathrm{G} \alpha_{16}$ (and $\mathrm{G} \alpha_{\mathrm{q}}$ ) is degraded through proteasome pathway [16]. Proteasome inhibitors like MG132 and lactacystin block the $\mathrm{G} \alpha_{16}$ degradation, whereas other non-proteasomal inhibitors show no obvious protection. The rate of degradation increases in the case of a palmitoylation-deficient mutant of $\mathrm{G} \alpha_{16}$, indicating that receptor-induced cytosolic translocation of $\mathrm{G} \alpha_{16}$ may facilitate its proteasomal degradation. Although there is no evidence for direct ubiquitination of $\mathrm{G} \alpha_{16}$ in that study, two potential non-consensus ubiquitination sites $\left(\mathrm{Arg}^{37}\right.$ and $\mathrm{Arg}^{302}$ ) can be found [17]. It would be interesting to examine if ubiquitination of $\mathrm{G} \alpha_{16}$ occurs in vivo.

\section{Promiscuous Receptor Coupling of $\mathrm{G}_{16}$}

One of the interesting features of $\mathrm{G}_{16}$ is its promiscuous receptor-coupling property, which channels a wide variety of GPCRs to activate PLC $\beta$ and induce rapid intracellular $\mathrm{Ca}^{2+}$ mobilization (table 1) [18]. Such a discovery has facilitated the deorphanization of novel GPCRs and a number of successful cases have been reported [reviewed in 19-21]. However, $G \alpha_{16}$ is far from being the ideal 'universal adaptor' for all kinds of GPCRs. Significant and increasing numbers of GPCRs are found to be incapable of recognizing $G_{16}$ [discussed in 22, 23] and most of them belong to the $\mathrm{G}_{\mathrm{i}}$-coupled receptors. The quest of a 'better coupler' has evolved based on the early finding that the extreme C-terminal tails of $\mathrm{G} \alpha$ subunits determine the receptor-coupling specificity $[24,25]$. Substitutions of the C-terminal residues in the $\alpha 5$ helix of $\mathrm{G} \alpha_{16}$ with those of either $\mathrm{G} \alpha_{\mathrm{i} 2}, \mathrm{G} \alpha_{\mathrm{o} 1}$ or $\mathrm{G} \alpha_{\mathrm{z}}$ can greatly enhance the coupling with $\mathrm{G}_{\mathrm{i}}$-linked receptors that normally do not interact with $G \alpha_{16}[23,26]$. The same strategy worked equally well for $\mathrm{G}_{\mathrm{s}}$-coupled receptors [27]. Chimeric $\mathrm{G} \alpha_{16}$ subunits with broadened receptor-coupling capability have been successfully employed in high throughput screening platforms [23, 28-30]. Further efforts have been made to decipher the minimal requirements for switching the receptor-coupling specificity. Individual residue lying on the exposed surface of the $\alpha 5$ helix of $\mathrm{G \alpha}_{16}$, as well as a stretch of six amino acids between the $\alpha 5$ helix and the extreme C-terminal tail, plays an important role in determining the receptor-coupling specificity [30]. Other potential receptor-interacting regions on $\mathrm{G} \alpha_{16}$ have also been explored, such as the $\beta 2 / \beta 3$ loop [30], $\alpha \mathrm{N} / \beta 1$ loop [31], as well as the uniquely long $\alpha 4 / \beta 6$ loop (fig. 1) [14]. Preliminary data from our laboratory indicate that reduction of the long $\alpha 4 / \beta 6$ loop of $\mathrm{G} \alpha_{16}$ can greatly diminish the receptor-coupling profile [M.K.C. Ho and Y.H. Wong, unpubl. data].

Ligand selectivity may reflect the distinct conformations of a GPCR in association with different $G$ proteins [reviewed in 32]. Since $G_{16}$ couples to a great variety of GPCRs, the coexistence of $G \alpha_{16}$ with other $G \alpha$ subunits in the same cellular milieu may modify the ligand selectivity of $\mathrm{a} \mathrm{G}_{16}$-coupled receptor. Emerging experimental evidence speaks for the hypothesis. Binding of specific agonist U50,488 to the $\mathrm{\kappa}$-opioid receptor (OR) activates $\mathrm{G}_{16}$ in COS-7 cells [33]. Yet, co-expression of $\mathrm{\kappa}-\mathrm{OR}$ with $\delta$-OR or OR-like receptor 1 , but not $\mu$-OR, attenuates the U50,488-elicited $\mathrm{G}_{16}$-mediated PLC $\beta$ activation [34]. Conformational changes of the 6th and 7th membrane-spanning helices of $\kappa$-OR have been studied by substituting cysteine residues with serines and assessing their accessibilities by sulfhydryl reagent (2-aminoethyl)methanethiosulfonate. Interestingly, non-overlapping cysteine residues are found to be sensitive to the sulfhydryl reagent when $\mathrm{K}-\mathrm{OR}$ is co-expressed with either $\mathrm{G} \alpha_{16}$ or $\mathrm{G} \alpha_{\mathrm{i} 2}$ [35]. Furthermore, the affinity of salvinorin A and U69593, but not dynorphin A (1-13), towards $\kappa^{-} \mathrm{OR}$ is significantly enhanced when $\mathrm{G}_{16}$ is coexpressed [35]. These results suggest that $G_{16}$ can functionally alter the ligand selectivity of the coupled receptor, thereby affecting the pharmacological outcome through the confinement of a subpopulation of the receptors at a particular active state. The concept of receptor-based biased functional selectivity caused by the presence of a defined set of $G$ proteins $[36,37]$ has been reported $[38,39]$. This phenomenon of biased ligand may profoundly affect the functions of GPCRs that are coupled to $\mathrm{G}_{16}$.

\section{Transcriptional Activation by $\mathbf{G} \alpha_{16}$}

It is believed that $\mathrm{G} \alpha_{16}$ has highly organized mechanisms for sorting and amplifying transmembrane signals due to its finely tuned expression regulation. With its unique expression in the hematopoietic lineages, it is plausible that $\mathrm{G} \alpha_{16}$ may play a role in hematopoietic cell differentiation and function. Although the underlying mechanisms as to how $\mathrm{G} \alpha_{16}$ is involved in the regulation of lineage exclusion and maturation remain elusive, there is evidence suggesting that $\mathrm{G} \alpha_{16}$ mediates the activation of several important transcription factors such as STATs and NF- $\kappa \mathrm{B}$. In combination of the importance of the 
Table 1. Receptor-coupling specificity of $\mathrm{G}_{16}$

\begin{tabular}{|c|c|c|c|}
\hline Receptor category & Subtype & $\begin{array}{l}\mathrm{G}_{15 / 16^{-}} \\
\text {coupled? }\end{array}$ & References \\
\hline \multicolumn{4}{|l|}{$G_{i}$-coupled receptors } \\
\hline Adenosine & $\mathrm{A}_{1}$ & $\mathrm{G}_{15 / 16}$ & 23,90 \\
\hline Adrenergic & $\alpha_{2}$ & $\mathrm{G}_{16}$ & 23 \\
\hline Cannabinoid & $\mathrm{CB}_{1}$ & $\mathrm{G}_{16}$ & 91 \\
\hline Chemoattractant & C3a, C5a, fMLP & $\mathrm{G}_{15 / 16}$ & $18,23,92-94$ \\
\hline \multirow[t]{2}{*}{ Chemokine } & $\begin{array}{l}\text { CCR1, CCR2b, CCR3, } \\
\text { CXCR1, CXCR2 }\end{array}$ & $\mathrm{G}_{16}$ & $95-97$ \\
\hline & CCR2a, CCR5, CCR7, CXCR4 & No & 95, 96, AUD \\
\hline Dopamine & $\mathrm{D}_{2}$ & $\mathrm{G}_{16}$ & 23 \\
\hline$\gamma$-Aminobutyric acid, metabotropic & $\begin{array}{l}\mathrm{GABA}_{\mathrm{B} 1 \mathrm{a}}+\mathrm{GABA}_{\mathrm{B} 2} \\
\mathrm{GABA}_{\mathrm{B} 1 \mathrm{~b}}+\mathrm{GABA}_{\mathrm{B} 2}\end{array}$ & $\mathrm{G}_{16}$ & 28 \\
\hline \multirow[t]{2}{*}{ Glutamate, metabotropic } & Drosophila, $\mathrm{mGlu}_{2}$ & $\mathrm{G}_{15 / 16}$ & 98 \\
\hline & $\mathrm{mGlu}_{4 \mathrm{a}}, \mathrm{mGlu}_{7 \mathrm{a}}, \mathrm{mGlu}_{8 \mathrm{a}}$ & $\mathrm{G}_{15}$ only & 98 \\
\hline \multirow[t]{2}{*}{ Melatonin } & $\mathrm{MT}_{1}, \mathrm{MT}_{2}$ & $\mathrm{G}_{16}$ & 23 \\
\hline & Xenopus & No & 23 \\
\hline \multirow[t]{2}{*}{ Muscarinic acetylcholine } & $\mathrm{M}_{2}$ & $\mathrm{G}_{15 / 16}$ & 18,99 \\
\hline & $\mathrm{M}_{4}$ & $\mathrm{G}_{15}$ only & 90 \\
\hline Neuropeptide & $\mathrm{AF} / \mathrm{FF}$ & $\mathrm{G}_{16}$ & 100 \\
\hline \multirow[t]{2}{*}{ Opioid } & $\mu$ & $\mathrm{G}_{15 / 16}$ & 18,33 \\
\hline & $\delta$, $\kappa$, nociceptin & $\mathrm{G}_{16}$ & 33 \\
\hline Purinergic & UDP-glucose & $\mathrm{G}_{16}$ & 101 \\
\hline Serotonin & $5-\mathrm{HT}_{1 \mathrm{~A}}$ & $\mathrm{G}_{15 / 16}$ & 18 \\
\hline Somatostatin & $\mathrm{SST}_{1}, \mathrm{SST}_{2}$ & $\mathrm{G}_{15 / 16}$ & 23,90 \\
\hline \multirow[t]{2}{*}{ Tastant/L-amino acids } & mouse $\mathrm{T} 2 \mathrm{R}_{5}$, human $\mathrm{T} 2 \mathrm{R}_{16}$ & No & 102 \\
\hline & $\mathrm{T} 1 \mathrm{R}_{1}+\mathrm{T} 1 \mathrm{R}_{3}, \mathrm{~T} 1 \mathrm{R}_{2}+\mathrm{T} 1 \mathrm{R}_{3}$ & $\mathrm{G}_{15}$ only & 103,104 \\
\hline Smoothened & - & $\mathrm{G}_{15}$ only & 105,106 \\
\hline \multicolumn{4}{|l|}{$G_{s}$-coupled receptors } \\
\hline Adenosine & $\mathrm{A}_{2 \mathrm{~A}}$ & $\mathrm{G}_{15 / 16}$ & 18,23 \\
\hline \multirow[t]{2}{*}{ Adrenergic } & $\beta_{1}$ & $\mathrm{G}_{16}$ & 99 \\
\hline & $\beta_{2}$ & $\mathrm{G}_{15 / 16}$ & $18,23,99$ \\
\hline \multirow[t]{2}{*}{ Dopamine } & $\mathrm{D}_{1}$ & $\mathrm{G}_{15 / 16}$ & 18,23 \\
\hline & $\mathrm{D}_{5}$ & $\mathrm{G}_{16}$ & 27 \\
\hline Glucagon & & No & 27 \\
\hline Histamine & $\mathrm{H}_{2}$ & $\mathrm{G}_{16}$ & 27 \\
\hline Luteinizing hormone & & $\mathrm{G}_{16}$ & 23,99 \\
\hline Parathyroid hormone & & $\mathrm{G}_{16}$ & 27 \\
\hline Prostaglandin & IP & $\mathrm{G}_{16}$ & AUD \\
\hline Secretin & & $\mathrm{G}_{16}$ & 27 \\
\hline Thyrotropin-releasing hormone & & $\mathrm{G}_{16}$ & 27 \\
\hline Vasoactive intestinal peptide & & $\mathrm{G}_{15}$ only & 90 \\
\hline Vasopressin & $\mathrm{V}_{2}$ & $\mathrm{G}_{15 / 16}$ & $18,23,99$ \\
\hline \multicolumn{4}{|l|}{$G_{q}$-coupled receptors } \\
\hline \multirow[t]{2}{*}{ Adrenergic } & $\alpha_{1 \mathrm{~A}}, \alpha_{1 \mathrm{C}}$ & No & 23 \\
\hline & $\alpha_{1 \mathrm{~B}}$ & $\mathrm{G}_{16}$ & 107 \\
\hline Bombesin & & $\mathrm{G}_{16}$ & 23 \\
\hline Metabotropic glutamine & $\mathrm{mGlu}_{1 \mathrm{a}}$ & No & 98 \\
\hline Muscarinic acetylcholine & $\mathrm{M}_{1}, \mathrm{M}_{3}, \mathrm{M}_{5}$ & $\mathrm{G}_{16}$ & 23, AUD \\
\hline Serotonin & $5-\mathrm{HT}_{1 \mathrm{C} / 2 \mathrm{C}}$ & $\mathrm{G}_{15 / 16}$ & 18 \\
\hline Thrombin & & $\mathrm{G}_{15 / 16}$ & 18 \\
\hline Thromboxane & $\mathrm{TXA}_{2}$ & $\mathrm{G}_{15 / 16}$ & 18 \\
\hline Vasopressin & $\mathrm{V}_{1 \mathrm{~A}}$ & $\mathrm{G}_{15 / 16}$ & 18 \\
\hline
\end{tabular}


transcription factors regulated by $\mathrm{G} \alpha_{16}$ and its promiscuity in the coupling of the receptors, many GPCRs would possess the ability to modulate the activities of the transcription factors in response to signals from the extracellular surroundings. Vasoconstrictors such as arginine vasopressin or angiotensin II induce hypertrophy of the vascular smooth muscle cells (VSMC) [40, 41]. Stable expression of constitutively active $\mathrm{G} \alpha_{16} \mathrm{QL}$ in VSMC stimulated c-Jun N-terminal kinase (JNK) activity, causing hypertrophy of the cells [42]. These results indicate that arginine vasopressin or angiotensin II signals through $\mathrm{G} \alpha_{16}$-coupled receptor, causing the VSMC hypertrophy in a JNK-dependent manner.

In human erythroleukemia (HEL) cells where $\mathrm{G} \alpha_{16}$ and $\mathrm{G} \alpha_{14}$ are endogenously expressed, stimulation of the prostacyclin receptor by its specific agonist cicaprost induces STAT1 and STAT3 phosphorylation in a PTX-insensitive manner. In addition, phosphorylations of extracellular signal-regulated kinase (ERK) and JNK, but not p38 mitogen-activated protein kinase, can also be induced by cicaprost [43]. Another study indicated that in human embryonic kidney 293 (HEK293) cells expressing a STAT3-responsive luciferase reporter, the $\mathrm{G}_{16}$-coupled opioid receptor-like $\left(\mathrm{ORL}_{1}\right)$ and formyl peptide (fMLP) receptors stimulated luciferase activity upon stimulation by specific agonists. Co-expression of $\mathrm{G} \alpha_{16}$ was required and the GPCR-mediated STAT3 activation was dependent on JAK and Raf-1 signaling [44]. More detailed illustration for the requirements of PLC $\beta / \mathrm{PKC} / \mathrm{CaMKII}$, Ras/Raf-1/ERK and Racl in the activation of STAT3 is accomplished by the application of constitutively active $\mathrm{G} \alpha_{16}\left(\mathrm{G} \alpha_{16} \mathrm{QL}\right)$ in heterologous expression systems using HEK293 cells. The non-receptor tyrosine kinases, c-Src, JAK2 and JAK 3 are also involved as demonstrated by the use of specific inhibitors and dominant-negative mutants (fig. 2) [45]. G $\alpha_{16} \mathrm{QL}$ induces STAT1-dependent $c$-fos transcriptional activation via PLC $\beta, c-S r c / J A K$ and ERK pathways [46]. The differential involvements of STAT1 and STAT3 in $\mathrm{G} \alpha_{16}$-induced signaling pathways reveals that there are functional differences between these two STAT proteins, although they can always be activated by the same stimuli and form homo- and heterodimers [47, 48]. The biological effects of these two proteins can be antagonistic, as revealed by their actions on cell growth and survival. Given that $\mathrm{G}_{16}$ can activate STAT1 and STAT3 simultaneously, the ultimate response of a particular cell type will depend on the availability of the two STAT proteins as well as the delicate control of the balanced levels between the homo- and/or heterodimer of STAT1 and STAT3.

Promiscuity and Specificity of $\mathrm{G} \alpha_{16}$ Signaling - A Hematopoietic Perspective

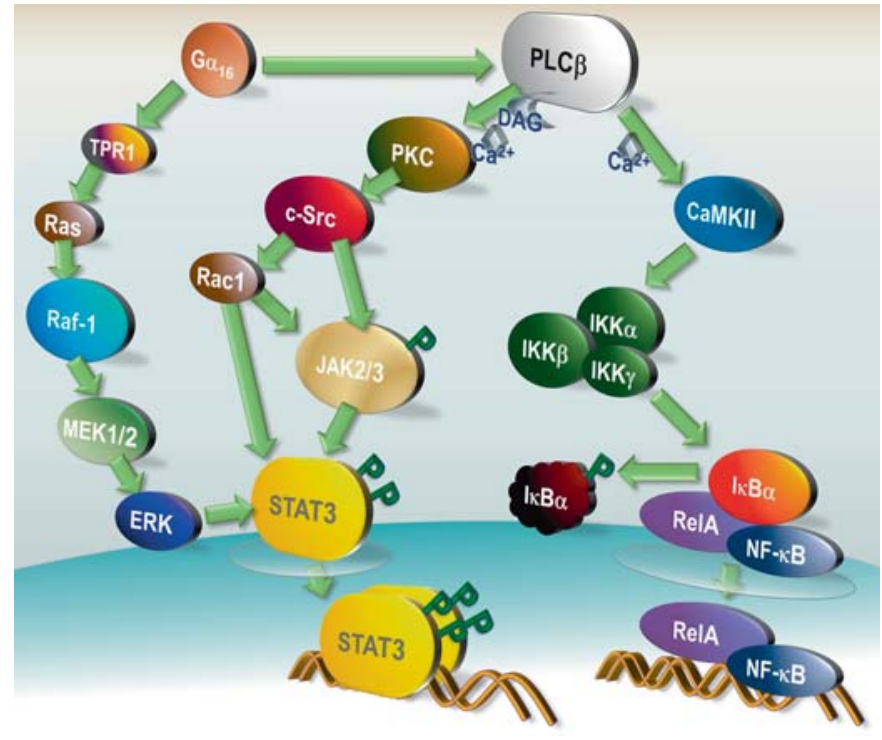

Fig. 2. Transcriptional stimulation of NF- $\kappa$ B and STAT3 by activated $\mathrm{G} \alpha_{16}$. GTP-bound $\mathrm{G} \alpha_{16}$ stimulates PLC $\beta / \mathrm{PKC} / \mathrm{CaMKII}$ and Ras/Raf-1/MEK/ERK signaling cascades, leading to the activation of STAT3. Activated $\mathrm{G} \alpha_{16}$ indirectly interacts with c-Src, which in turn activates JAK/STAT pathway. Racl is required for the full activation of STAT3. Additionally, through both $\mathrm{G} \alpha_{16}$ and activation-released G $\beta \gamma$, Ras/Raf-1/MEK/ERK pathway and cSrc become activated, which lead to the stimulation of IKK, followed by the phosphorylation and degradation of ІкB $\alpha$. The unsequestered p65/p50 heterodimer then translocates into the nucleus, and promotes NF- $\kappa \mathrm{B}$-dependent transcription. The adaptor protein TPR 1 bridges the interaction between activated $\mathrm{G} \alpha_{16}$ and Ras, which contributes to the activation of STAT3 and NF-кB. P stands for the phosphorylation site.

In addition to the regulation of STAT activity, $\mathrm{G \alpha}_{16}$ can couple to chemoattractant receptors such as CCR8, $\mathrm{C} 3 \mathrm{a}, \mathrm{C} 5 \mathrm{a}$, and $\mathrm{fMLP}$ receptors to activate NF- $\kappa \mathrm{B}$, but the detailed signaling pathways involved have not been delineated $[49,50]$. In the resting state, the two subunits of $\mathrm{NF}-\kappa \mathrm{B}, \mathrm{p} 65$ and $\mathrm{p} 50$, are retained in the cytosol by anchoring to the inhibitor- $\kappa \mathrm{B} \alpha(\mathrm{I} \kappa \mathrm{B} \alpha)$. Upon cell activation, an upstream IкB kinase (IKK) complex comprised of the catalytic subunits (IKK $\alpha$ and IKK $\beta$ ) and a linker subunit (IKK $\gamma$ ) becomes activated, and subsequently phosphorylates I $\mathrm{B} \alpha$, leading to the degradation of Iк $\mathrm{B} \alpha$. The released heterodimer then translocates into the nucleus and promotes NF- $\kappa \mathrm{B}$-dependent transcription. Studies of other $\mathrm{G}_{16}$-coupled receptors provide hints on how $G_{16}$ may regulate NF- $\kappa B$. Adenosine $A_{1}$ receptor $\left(\mathrm{A}_{1} \mathrm{R}\right)$ can couple to both $\mathrm{G} \alpha_{\mathrm{i}}[51]$ and $\mathrm{G} \alpha_{16}$ proteins [23, 33]. Stimulation of Reh cells with $A_{1} R$ agonist, $\mathrm{N}^{6}$-cyclohexyladenosine, results in PTX-insensitive phosphoryla-

Neurosignals 2009;17:71-81 
tion of IKK. Interestingly, only Reh cells expressing $\mathrm{G} \alpha_{16}$ supported the $\mathrm{N}^{6}$-cyclohexyladenosine-induced IKK phosphorylation and NF- $\mathrm{KB}$-driven luciferase activity. Further examination revealed the participation of c-Src, as well as signaling intermediates along ERK cascade including Ras, Raf- 1 and MEK1/2, in G $\alpha_{16}$-dependent NF$\kappa \mathrm{B}$ activation in the Reh cells (fig. 2) [52].

The ability to integrate incoming signals is an important feature of biological systems. The final biological response is the combinational consequences of cell-type specificities, the strength and duration of the signals, and the balanced effects between the elicited signaling pathways. More than one transcription factor might be activated upon encountering a single extracellular stimulation. Recent studies from our laboratory have demonstrated that Lkn-1 stimulation of $\mathrm{G} \alpha_{16} / \mathrm{G} \alpha_{14}$-coupled CCR1 leads to the activation of both STAT3 and NF- $\kappa B$ in HEK293 cells expressing CCR1 together with $\mathrm{G} \alpha_{14}$ or $\mathrm{G} \alpha_{16}$ [unpubl. data]. $\mathrm{G} \alpha_{16}$ may be involved in the modulation of growth factor receptor signaling. Exogenous expression of $\mathrm{G}_{16} \mathrm{QL}$ in Swiss 3T3 cells results in the growth inhibition of the cells, and downregulation of the signal pathway in response to platelet-derived growth factor [53]. Transfection of constitutively active $\mathrm{G} \alpha_{16} \mathrm{QL}$ markedly enhance tumor necrosis factor- $\alpha$-induced NF$\kappa \mathrm{B}$ reporter activity in HeLa cells [50]. It has also been revealed that preactivation of $\mathrm{G} \alpha_{\mathrm{q}}$ family members including $G \alpha_{16}$ permits subsequent stimulation of PLC $\beta$ by $\mathrm{G}_{\mathrm{i}}$-coupled receptors through the release of $\mathrm{G} \beta \gamma$ dimer. In transiently transfected COS-7 cells, agonists binding of the $\mathrm{G}_{\mathrm{i}}$-coupled $\delta$ - and $\kappa$-opioid receptors cannot stimulate PLC $\beta$ unless they are co-expressed with $\mathrm{G}_{16}$ [54]. Another study shows that leukotriene $\mathrm{B}_{4}$ receptor can activate $\mathrm{PLC}_{2}$-mediated IP accumulation via $\mathrm{G} \alpha_{\mathrm{i} 2}$-derived $G \beta \gamma$, and a synergistic effect could be observed when these cells co-express $G \alpha_{16}$ [55]. Given that both $\mathrm{G} \alpha_{\mathrm{i} 2}$ and $\mathrm{G} \alpha_{16}$ are expressed in the hematopoietic cells [1, 56], the physiological relevance of the synergistic actions mediated by these two $\mathrm{G} \alpha$ subunits deserves further investigations. Altogether, these studies suggest that activation of $\mathrm{G}_{16}$ can synergize the effects of cytokines and other GPCRs in regulating transcriptional events.

\section{Binding Partners of $\mathbf{G} \alpha_{16}$}

New insights on the functions of $\mathrm{G}_{16}$ can be gleaned from the discovery of novel binding partners of $\mathrm{G}_{16}$. Recently, an adaptor protein called tetratricopeptide repeat 1 (TPR1) was found to bind to $G \alpha_{16}$ in yeast two-hybrid screening [57]. TPR1 is a 292 -amino-acid protein containing three TPR motifs that was originally identified in the yeast cell division cycle protein Cdc23p [58] and the nuclear protein nuc2 [59], and was subsequently found to be present in many other proteins [60]. It has been demonstrated that TPR1 interacts with Ha-Ras preferentially in its active form. Expression of $G \alpha_{16}$, especially its constitutively active form strongly enhances the interaction between TPR1 and Ras (fig. 1) [57]. In an attempt to define the structural requirement for $\mathrm{G} \alpha_{16}$ to interact with TPR1, a series of G $\alpha$ chimeras have been constructed in our laboratory to test for their association with TPR1. Our preliminary data indicated that a stretch of six amino acids (201-206) in the $\beta 3$ region of $G \alpha_{16}$ is required for interaction with TPR1 without affecting the activation of PLC $\beta$. Further experiments confirmed that the identified region is devoid of PLC $\beta$-stimulating activity. It appears that there are two discrete functional regions of $\mathrm{G} \alpha_{16}$ for the activation of PLC $\beta$ and Ras, two signaling molecules important for the induction of downstream transcription factors such as STAT3 and NF- $\mathrm{B}$ [unpubl. data].

Regulators of $\mathrm{G}$ protein signaling (RGS) protein binds to the active $G \alpha$ subunits and stabilizes the transition state of G $\alpha$-catalyzed GTP hydrolysis, resulting in the acceleration of GTP hydrolysis, and therefore, termination of $G$ protein signaling [61]. Among the more than 30 RGS proteins identified to date, only RGS2 has been shown to interact with $G \alpha_{16}$ and block of PLC $\beta$ signaling. RGS2 also inhibited IP production in HEK293 cells expressing the constitutively active $\mathrm{G} \alpha_{16} \mathrm{QL}$ [62]. Interestingly, GRK2 (a GPCR kinase bearing some resemblance to RGS proteins) selectively interacts with $\mathrm{G} \alpha_{\mathrm{q}}$ over $\mathrm{G} \alpha_{16}$ [62]. GRK2 binds to the 'switch loops' of $\mathrm{G} \alpha_{\mathrm{q}}$ and inhibits its signaling [63]. The amino acid sequence of the switch loop region of $\mathrm{G} \alpha_{16}$ is notably different from that in other $\mathrm{G} \alpha_{\mathrm{q}}$ subfamily members [3], which might account for the discrimination between $G \alpha_{\mathrm{q}}$ and $\mathrm{G} \alpha_{16}$ in their binding to GRK2. It is possible that $\mathrm{G} \alpha_{16}$ may interact with a unique array of RGS and RGS-like proteins.

Another recently identified $\mathrm{G}_{16}$-binding partner, p63RhoGEF, belongs to the guanine nucleotide exchange factor (GEF) family. p63RhoGEF contains the Dbl and pleckstrin homology domains [64], and has been described as a novel mediator of $\mathrm{G} \alpha_{\mathrm{q} / 11}$ signaling to enhance RhoA activation $[65,66]$. Physical association between $\mathrm{G} \alpha_{16}$ and $\mathrm{p} 63 \mathrm{RhoGEF}$ has been recently demonstrated in our laboratory. Further investigation revealed that instead of the enhancement of RhoA signal, overexpression of $\mathrm{p} 63 \mathrm{R}$ hoGEF and $\mathrm{G} \alpha_{16}$ in HEK293 cells inhibits PLC $\beta 2$ 
activation and its downstream signaling such as the stimulation of transcription factors STAT3 and NF- $\kappa \mathrm{B}$ [unpubl. data]. These results suggest that p63RhoGEF may play differential roles in regulating the signaling of different $\mathrm{G}_{\mathrm{q}}$ subfamily members.

\section{$\mathbf{G} \alpha_{16}$ Expression during Myeloid Differentiation}

$\mathrm{G} \alpha_{16}$ expression fluctuates significantly during lineage differentiation $[1,67]$. The pluripotent hematopoietic stem cells in the bone marrow can be divided into two types of progenitors - a common lymphoid progenitor that gives rise to natural killer cells and $\mathrm{T}$ and $\mathrm{B}$ lymphocytes, and a common myeloid progenitor that gives rise to different types of leukocytes, erythrocytes and megakaryocytes that produce platelets. The leukocytes include monocytes, the myeloid dendritic cells, and neutrophils, eosinophils and basophils. The latter three are generally termed granulocytes. $\mathrm{G} \alpha_{16}$ protein expression is high in normal CD34 ${ }^{+}$cells $(\mathrm{CD} 34$ is the surface marker for the hematopoietic progenitor cells), then decreases sharply when differentiating into granulocytes and erythrocytes [67]. In contrast, expression of $\mathrm{G} \alpha_{16}$ protein remains high during normal monocytic differentiation and in HL60 cells (committed myeloid precursor cell line) differentiating into monocytes when induced by phorbol 12-myristate 13-acetate (PMA) or interferon- $\gamma$ [67]. Acute leukemias are clonal diseases in which the malignant cells lose their differentiation capacity. In primary myeloid leukemoblasts, as well as leukemic cell lines such as myeloid leukemia HL60, KG-1, $\mathrm{HEL}$, and $\mathrm{K} 562$ cells, expression of $\mathrm{G} \alpha_{16}$ protein is higher than that found in their normal $\mathrm{CD} 34^{+}$counterparts $[1,67]$. These results imply that $\mathrm{G \alpha}_{16}$-dependent signaling may modulate cell proliferation or differentiation, depending on the specific cellular environment. Therefore, elucidating the functions of $\mathrm{G} \alpha_{16}$ in hematopoietic cells, and identifying the surface receptors to which they couple, should lead to a better understanding of the mechanisms regulating human hematopoiesis and leukemogenesis.

Further information about the potential roles of $\mathrm{G}_{16}$ accumulated from studies in which $\mathrm{G} \alpha_{16}$ expression level or functional activity was altered. HEL cells endogenously express the $\mathrm{P}_{2} \mathrm{Y}_{2}$ purinergic receptor that is coupled to $\mathrm{G} \alpha_{16}$. $\mathrm{P} 2 \mathrm{Y}_{2}$-mediated elevation of intracellular $\mathrm{Ca}^{2+}$ is suppressed in HEL cells expressing antisense $\mathrm{G \alpha}_{16}$; the growth rate is also impaired in this cell line [68]. In MB02 erythroleukemia cells containing a GFP-reporter sys- tem that associates with erythroid differentiation, overexpression of wild type, constitutively active $G \alpha_{16}$, or transfection of a $G \alpha_{16}$ antisense plasmid led to significant growth inhibition and differentiation promotion [69]. This data indicate that an optimal functional level of $\mathrm{G} \alpha_{16}$ is required for maintaining MB-02 cell proliferation, and any deviation from it will induce cell differentiation.

\section{$\mathbf{G} \alpha_{16}$ Expression during B-Cell Differentiation}

In accordance with its expression in myeloid lineage, $\mathrm{G} \alpha_{16}$ expression is restricted to progenitor B cells and poorly differentiated B-cell malignancies such as pre-Bacute lymphocytic leukemia, but not in its differentiated counterparts such as peripheral mature B cells and nonHodgkin's lymphoma $[1,70]$. When a pre-B-cell line BLIN-1 is stimulated to undergo maturation development, $G \alpha_{16}$ expression was found to disappear during the transition from pre-B to B-cell differentiation stages [70].

The $\mathrm{G}_{16}$-associated cell surface receptor of B-cell origin is largely unknown. However, there are several pieces of data indicating that GPCRs do exist on B cells and they might play important functional roles in modifying B-cell proliferation and differentiation. In blood cells, the most abundant known GPCRs are receptors for chemokines [71]. Other than the transduction of chemotactic signals, a number of chemokines are also believed to have functions in hematopoietic proliferation and differentiation. Although the definitive influence of chemoattractants on B cells remains elusive, recent studies have demonstrated that there is stage-specific microenvironment (niches) in the bone marrow for the development of B-cell progenitors [72]. A chemokine called stromal-derived factor-1 (SDF-1) plays a pivotal role in the migration and retention of $\mathrm{B}$-cell progenitors in the bone marrow niches, which might indirectly affect their differentiation via cellular compartmentalization $[73,74]$.

A number of viruses make use of GPCR mimetics to hijack our immune system. Kaposi's sarcoma-associated herpesvirus (KSHV) infects B cells and expresses a viral IL-8 receptor-like GPCR (KSHV-GPCR) which is constitutively active and also capable of binding various CXC chemokines including IL-8, SDF-1, IP-10 (interferon- $\gamma$-inducible protein-10) $[75,76]$. Exogenous expression of KSHV-GPCR in BJAB cells upregulates numerous cellular transcripts. The most abundantly in- 
duced genes are the CC chemokines macrophage inflammatory protein (MIP)- $1 \alpha$ and $-1 \beta$ [77]. Activation of KSHV-GPCR induces the tyrosine phosphorylation of RAFTK (related adhesion focal tyrosine kinase, also known as Pyk2 and $C A K \beta$ ), a kinase that can be activated when cross-linking the $\mathrm{B}$-cell receptor and acts as an oncogene to stimulate JNK and p38 [78]. Consequently, there appears to be a functional cross-talk between signals generated by ligation of B-cell receptor and KSHV-GPCR, leading to modulation of B-cell proliferation $[78,79]$.

There is no evidence to indicate how $\mathrm{G} \alpha_{16}$ might affect B-cell differentiation in the bone marrow. Strikingly, as revealed in an early report, PLC $\beta$ was not expressed in murine B cells throughout all developmental stages [80]. Therefore, signals elicited by $\mathrm{G} \alpha_{16}$-coupled receptors may not go through the conventional PLC $\beta$-engaged pathways. Data from our laboratory suggests that activated $\mathrm{G} \alpha_{16}$ may induce the activation of transcription factors in a PLC $\beta$-independent manner. Interaction between $G \alpha_{16}$ and TPR1 allows the coupling of diverse receptors to the stimulation of Ras, as well as the subsequent activation of STAT3 [57]. A recent study shows that the absence of STAT3 impaired bone marrow B-cell development. Mice selectively lacking STAT3 in the bone marrow progenitor cells display reduced numbers of mature B cells which is believed to result from the diminished numbers of B-cell precursors including pro-, pre-, and immature B cells [81]. Given the fact that TPR1 is universally expressed and the fact that $\mathrm{G} \alpha_{16}$ expression is dramatically disrupted during pre-B- to B-cell transition, it is conceivable that $\mathrm{G} \alpha_{16}$ may regulate $\mathrm{B}$-cell differentiation by modulating gene transcription at particular developmental stages through its interaction with TPR1.

\section{$\mathbf{G} \alpha_{16}$ Expression during T-Cell Activation}

$\mathrm{T}$ cells originate from the hematopoietic stem cells in the bone marrow, and develop into mature naive $\mathrm{T}$ cells $\left(\mathrm{CD} 4^{+}\right.$or $\left.\mathrm{CD}^{+}\right)$in the thymus. Many $\mathrm{G} \alpha$ subunits including $\mathrm{G} \alpha_{\mathrm{q} / 11}$ and $\mathrm{G} \alpha_{16}$ have been identified in human thymocytes [82]. It has been suggested that a coordinated regulation of $\mathrm{G} \alpha_{16}$ expression is required for optimal $\mathrm{T}$ cell activation: $\mathrm{G} \alpha_{16}$ protein expression reaches the highest level at day 4 in blood T cells after Leuco A stimulation and then decreases afterwards. Responses to Leuco A in Jurkat $\mathrm{T}$ cell are strongly inhibited when $\mathrm{G} \alpha_{16}$ is overexpressed, and surprisingly, weak inhibition has also been observed when increases in $\mathrm{G} \alpha_{16}$ expression were prevented expressing an antisense $\mathrm{G} \alpha_{16}$ construct [83]. Collectively, these data suggest that alterations of $\mathrm{G} \alpha_{16}$ expression impair activation-induced T-cell responses.

The T-cell receptor (TCR) complex consists of the highly variable $\alpha: \beta$ heterodimer which recognizes and binds antigen, the invariant CD3 complex (composed of $\mathrm{CD} 3 \gamma, \mathrm{CD} 3 \delta$, and $\mathrm{CD} 3 \varepsilon$ ) and $\zeta$ chains. Upon anti-CD3$\mathrm{mAb}$ engagement, $\mathrm{G} \alpha_{\mathrm{q} / 11}$ and $\mathrm{G} \alpha_{16}$ are activated [84], and TCR/CD3-mediated signaling is inhibited in Jurkat T cells expressing a dominant negative mutant of $\mathrm{G}_{16}$ [85]. A profound defect in the production of IL-2 and IL-10, as well as in the expression of CD69 was observed. Accordingly, significant reductions in anti- $\varepsilon$-induced tyrosine phosphorylation of $\zeta, \varepsilon$, ZAP-70 ( $\zeta$-associated protein 70 ) and intracellular $\mathrm{Ca}^{2+}$ mobilization are detected. Similarly, TCR/CD3-mediated activation of two Src-family tyrosine kinases, Fyn and Lck, are also reduced by the same $\mathrm{G} \alpha_{16}$ mutant. However, the PMA-induced IL-10 production and CD69 expression, and the ionomycin plus PMA-induced IL-2 production are not affected in mutant $\mathrm{G} \alpha_{16}$-expressed Jurkat cells. Together, these results imply a crucial functional role of $\mathrm{G}_{16}$ in TCR signaling. Recently, we have performed co-immunoprecipitation studies and confirmed that $\mathrm{G \alpha}_{16}$ is physically associated with the TCR, and the observed interaction is dependent on the activation of $G \alpha_{16}$ but not the T cells. Constitutively active $\mathrm{G} \alpha_{\mathrm{i}}$ subunits are unable to co-immunoprecipitate with the TCR, suggesting the specificity of the interaction between $\mathrm{G}_{16}$ and TCR [unpubl. data]. These studies provide further supportive evidence for the specific association between $\mathrm{G} \alpha_{16}$ and the TCR complex, and raise the possibility that signaling through $\mathrm{G \alpha}_{16^{-}}$ coupled receptors may affect the activation of $\mathrm{T}$ cells. Similar results have been obtained regarding the co-stimulation of T cells by chemokine receptors coupled to $\mathrm{G} \alpha_{\mathrm{q}}$ and/or $\mathrm{G} \alpha_{11}$ via their recruitment to the immunological synapse [86]. Altogether, these results increase our understanding of the molecular mechanisms responsible for the involvement of $\mathrm{G}_{16}$ in T-cell activation.

\section{Conclusion}

We have outlined the evidence demonstrating the distinctive biochemical properties of $\mathrm{G} \alpha_{16}$, together with its proven and speculated biological functions. Identification of the covalent modifications of $\mathrm{G} \alpha_{16}$, which are important for its membrane targeting and signal transduction, is extremely helpful in our appreciation of its func- 
tional activity. Sequence substitutions and mutations of $G \alpha_{16}$ help to illustrate the receptor binding promiscuity and advance our understanding of its receptor-coupling capability and specificity. Great achievements have been made in the delineation of the $\mathrm{G} \alpha_{16}$-associated signaling molecules and pathways involved in the activation of the transcription factors, which allow the appreciation to the complexity of the linked signaling network. $G \alpha_{16}$ is uniquely expressed in the hematopoietic cells and in tissues harboring these cells. Some progress about its functions in hematopoietic development and differentiation has been achieved since its discovery. However, due to technical limitations such as the low efficiency of hematopoietic cell transfection, and the complexity of lineage maturation network, questions as to how exactly $\mathrm{G} \alpha_{16}$ fits into the hematopoietic signaling and development remain unaddressed. The signaling complexity, and the re- ceptor binding promiscuity, together with its restrained cell/tissue distribution, raises the possibility that $G \alpha_{16}$ is able to elicit a unique profile of signaling events and cellular responses. It is of great interest in the future to investigate the biological function of $\mathrm{G \alpha}_{16}$ and its involvement in the cross-talk with other signaling pathways such as BCR- and TCR-induced lymphocyte differentiation and activation.

\section{Acknowledgements}

This work was supported in part by grants from the Research Grants Council of Hong Kong (HKUST 6120/04M and HKUST 3/03C), the University Grants Committee (AoE/B-15/01), and the Hong Kong Jockey Club. Y.H.W. was a recipient of the Croucher Senior Research Fellowship.

\section{References}

1 Amatruda TT 3rd, Steele DA, Slepak VZ, Simon MI: $\mathrm{G \alpha}_{16}$, a $\mathrm{G}$ protein $\alpha$ subunit specifically expressed in hematopoietic cells. Proc Natl Acad Sci USA 1991;88:5587-5591.

- Wilkie TM, Scherle PA, Strathmann MP, Slepak VZ, Simon MI: Characterization of G-protein $\alpha$ subunits in the $\mathrm{G}_{\mathrm{q}}$ class: expression in murine tissues and in stromal and hematopoietic cell lines. Proc Natl Acad Sci USA 1991;88:10049-10053.

-3 Strathmann M, Simon MI: G protein diversity: a distinct class of $\alpha$ subunits is present in vertebrates and invertebrates. Proc Natl Acad Sci USA 1990;87:9113-9117.

$\checkmark 4$ Bae H, Anderson K, Flood LA, Skiba NP, Hamm HE, Graber SG: Molecular determinants of selectivity in 5-hydroxytryptamin$\mathrm{e}_{1 \mathrm{~B}}$ receptor- $\mathrm{G}$ protein interactions. J Biol Chem 1997:272:32071-32077.

$\checkmark 5$ Ho MK, Wong YH: The amino terminus of $\mathrm{G \alpha}_{\mathrm{z}}$ is required for receptor recognition, whereas its $\alpha 4 / \beta 6$ loop is essential for inhibition of adenylyl cyclase. Mol Pharmacol 2000;58:993-1000.

6 Laerum OD, Frostad S, Ton HI, Kamp D: The sequence of the hemoregulatory peptide is present in $\mathrm{G}_{i} \alpha$ proteins. FEBS Lett 1990;269: 11-14.

-7 Paukovits WR, Hergl A, Schulte-Hermann R: Hemoregulatory peptide pGlu-Glu-AspCys-Lys: a new synthetic derivative for avoiding dimerization and loss of inhibitory activity. Mol Pharmacol 1990;38:401-409.

>8 Kozasa T, Hepler JR, Smrcka AV, Simon MI, Rhee SG, Sternweis PC, Gilman AG: Purification and characterization of recombinant $\mathrm{G}_{16} \alpha$ from Sf9 cells: activation of purified phospholipase C isozymes by G-protein $\alpha$ subunits. Proc Natl Acad Sci USA 1993;90: 9176-9180.

-9 Davignon I, Catalina MD, Smith D, Montgomery J, Swantek J, Croy J, Siegelman M, Wilkie TM: Normal hematopoiesis and inflammatory responses despite discrete signaling defects in $\mathrm{G}_{15}$ knockout mice. Mol Cell Biol 2000;20:797-804.

10 Pedone KH, Hepler JR: The importance of $\mathrm{N}$-terminal polycysteine and polybasic sequences for $G_{14} \alpha$ and $G_{16} \alpha$ palmitoylation, plasma membrane localization, and signaling function. J Biol Chem 2007;282:2519925212.

11 Qanbar R, Bouvier M: Role of palmitoylation/ depalmitoylation reactions in G-proteincoupled receptor function. Pharmacol Ther 2003;97:1-33.

12 Glick J, Santoyo G, Casey PJ: Arachidonate and related unsaturated fatty acids selectively inactivate the guanine nucleotide-binding regulatory protein, $\mathrm{G}_{\mathrm{z}}$. J Biol Chem 1996;271: 2949-2954.

13 Aragay AM, Quick MW: Functional regulation of $\mathrm{G} \alpha_{16}$ by protein kinase C. J Biol Chem 1999;274:4807-4815.

14 Gu JL, Lu W, Xia C, Wu X, Liu M: Regulation of hematopoietic-specific G-protein $\mathrm{G}_{15}$ and $\mathrm{G} \alpha_{16}$ by protein kinase C. J Cell Biochem 2003;88:1101-1111.

15 Lee CH, Katz A, Simon MI: Multiple regions of $\mathrm{G} \alpha_{16}$ contribute to the specificity of activation by the $\mathrm{C} 5 \mathrm{a}$ receptor. Mol Pharmacol 1995;47:218-223.

16 Johansson BB, Minsaas L, Aragay AM: Proteasome involvement in the degradation of the $\mathrm{G}_{\mathrm{q}}$ family of $\mathrm{G} \alpha$ subunits. FEBS J 2005 272:5365-5377.
17 Xue Y, Zhou F, Fu C, Xu Y, Yao X: SUMOsp: a web server for sumoylation site prediction. Nucleic Acids Res 2006;34:W254W257.

18 Offermanns S, Simon MI: $G \alpha_{15}$ and $G \alpha_{16}$ couple a wide variety of receptors to phospholipase C. J Biol Chem 1995;270:1517515180.

19 Szekeres PG: Functional assays for identifying ligands at orphan $\mathrm{G}$ protein-coupled receptors. Receptors Channels 2002;8:297308

20 Touhara K: Deorphanizing vertebrate olfactory receptors: recent advances in odorantresponse assays. Neurochem Int 2007;51: 132-139.

21 Wise A, Jupe SC, Rees S: The identification of ligands at orphan G-protein coupled receptors. Annu Rev Pharmacol Toxicol 2004; 44:43-66

22 Kostenis E: Is $G \alpha_{16}$ the optimal tool for fishing ligands of orphan G-protein-coupled receptors? Trends Pharmacol Sci 2001;22:560564

23 Mody SM, Ho MK, Joshi SA, Wong YH: Incorporation of $\mathrm{G \alpha}_{\mathrm{z}}$-specific sequence at the carboxyl terminus increases the promiscuity of $\mathrm{G \alpha}_{16}$ toward $\mathrm{G}_{\mathrm{i}}$-coupled receptors. Mol Pharmacol 2000;57:13-23.

24 Conklin BR, Farfel Z, Lustig KD, Julius D, Bourne HR: Substitution of three amino acids switches receptor specificity of $\mathrm{G}_{\mathrm{q}} \alpha$ to that of $\mathrm{G}_{i} \alpha$. Nature 1993;363:274-276.

25 Conklin BR, Herzmark P, Ishida S, VoynoYasenetskaya TA, Sun Y, Farfel Z, Bourne HR: Carboxyl-terminal mutations of $\mathrm{G}_{\mathrm{q}} \alpha$ and $\mathrm{G}_{\mathrm{s}} \alpha$ that alter the fidelity of receptor activation. Mol Pharmacol 1996;50:885-890. 
26 Wong CS, Ho MK, Wong YH: The $\beta 6 / \alpha 5$ regions of $\mathrm{G} \alpha_{\mathrm{i} 2}$ and $\mathrm{G} \alpha_{\mathrm{OA}}$ increase the promiscuity of $\mathrm{G} \alpha_{16}$ but are insufficient for pertussis toxin-catalyzed ADP-ribosylation. Eur J Pharmacol 2003;473:105-115.

-27 Hazari A, Lowes V, Chan JH, Wong CS, Ho MK, Wong YH: Replacement of the $\alpha 5$ helix of $\mathrm{G} \alpha_{16}$ with $\mathrm{G} \alpha_{\mathrm{s}}$-specific sequences enhances promiscuity of $\mathrm{G} \alpha_{16}$ toward $\mathrm{G}_{\mathrm{s}}$-coupled receptors. Cell Signal 2004;16:51-62.

28 Liu AM, Ho MK, Wong CS, Chan JH, Pau $\mathrm{AH}$, Wong $\mathrm{YH}: \mathrm{G}_{16 / \mathrm{z}}$ chimeras efficiently link a wide range of $G$ protein-coupled receptors to calcium mobilization. J Biomol Screen 2003;8:39-49.

29 New DC, Wong YH: Characterization of $\mathrm{CHO}$ cells stably expressing a $\mathrm{G} \alpha_{16 / z}$ chimera for high throughput screening of GPCRs. Assay Drug Dev Technol 2004;2:269-280.

- 30 Ho MK, Chan JH, Wong CS, Wong YH: Identification of a stretch of six divergent amino acids on the $\alpha 5$ helix of $\mathrm{G \alpha}_{16}$ as a major determinant of the promiscuity and efficiency of receptor coupling. Biochem J 2004;380:361-369.

- 31 Blahos J, Fischer T, Brabet I, Stauffer D, Rovelli G, Bockaert J, Pin JP: A novel site on the $\mathrm{G} \alpha$-protein that recognizes heptahelical receptors. J Biol Chem 2001;276:3262-3269.

- 32 Urban JD, Clarke WP, von Zastrow M, Nichols DE, Kobilka B, Weinstein H, Javitch JA, Roth BL, Christopoulos A, Sexton PM, Miller KJ, Spedding M, Mailman RB: Functional selectivity and classical concepts of quantitative pharmacology. J Pharmacol Exp Ther 2007;320:1-13.

33 Lee JW, Joshi S, Chan JS, Wong YH: Differential coupling of $\mu$-, $\delta$-, and $\kappa$-opioid receptors to $\mathrm{G \alpha}_{16}$-mediated stimulation of phospholipase C. J Neurochem 1998;70: 2203-2211.

-34 Ho MK, New DC, Wong YH: Co-expressions of different opioid receptor types differentially modulate their signaling via $\mathrm{G}_{16}$. Neurosignals 2002;11:115-122.

- 35 Yan F, Mosier PD, Westkaemper RB, Roth BL: $G \alpha$-subunits differentially alter the conformation and agonist affinity of $\kappa$-opioid receptors. Biochemistry 2008;47:1567-1578.

- 36 Kenakin T: Differences between natural and recombinant $G$ protein-coupled receptor systems with varying receptor/G protein stoichiometry. Trends Pharmacol Sci 1997; 18:456-464.

- 37 Kenakin T: Functional selectivity through protean and biased agonism: who steers the ship? Mol Pharmacol 2007;72:1393-1401.

- 38 Watson C, Chen G, Irving P, Way J, Chen WJ, Kenakin T: The use of stimulus-biased assay systems to detect agonist-specific receptor active states: implications for the trafficking of receptor stimulus by agonists. Mol Pharmacol 2000;58:1230-1238.

39 Mukhopadhyay S, Howlett AC: Chemically distinct ligands promote differential $\mathrm{CB}_{1}$ cannabinoid receptor- $\mathrm{G}_{\mathrm{i}}$ protein interactions. Mol Pharmacol 2005;67:2016-2024.
40 Geisterfer AA, Owens GK: Arginine vasopressin-induced hypertrophy of cultured rat aortic smooth muscle cells. Hypertension 1989;14:413-420.

41 Geisterfer AA, Peach MJ, Owens GK: Angiotensin II induces hypertrophy, not hyperplasia, of cultured rat aortic smooth muscle cells. Circ Res 1988;62:749-756.

42 Higashita R, Li L, Van Putten V, Yamamura Y, Zarinetchi F, Heasley L, Nemenoff RA: $\mathrm{G} \alpha_{16}$ mimics vasoconstrictor action to induce smooth muscle $\alpha$-actin in vascular smooth muscle cells through a Jun- $\mathrm{NH}_{2}$-terminal kinase-dependent pathway. J Biol Chem 1997;272:25845-25850.

43 Lo RK, Wise H, Wong YH: Prostacyclin receptor induces STAT1 and STAT3 phosphorylations in human erythroleukemia cells: a mechanism requiring PTX-insensitive G proteins, ERK and JNK. Cell Signal 2006;18: 307-317.

$44 \mathrm{Wu}$ EH, Lo RK, Wong YH: Regulation of STAT3 activity by $\mathrm{G}_{16}$-coupled receptors. Biochem Biophys Res Commun 2003;303: 920-925.

45 Lo RK, Cheung H, Wong YH: Constitutively active $\mathrm{G} \alpha_{16}$ stimulates STAT3 via a c-Src/ JAK- and ERK-dependent mechanism. J Biol Chem 2003;278:52154-52165.

46 Lo RK, Wong YH: Transcriptional activation of c-Fos by constitutively active $\mathrm{G} \alpha_{16} \mathrm{QL}$ through a STAT1-dependent pathway. Cell Signal 2006; 18:2143-2153.

47 Gouilleux-Gruart V, Debierre-Grockiego F, Gouilleux F, Capiod JC, Claisse JF, Delobel J, Prin L: Activated Stat-related transcription factors in acute leukemia. Leuk Lymphoma 1997;28:83-88.

48 Stancato LF, David M, Carter-Su C, Larner AC, Pratt WB: Preassociation of STAT1 with STAT2 and STAT3 in separate signalling complexes prior to cytokine stimulation. J Biol Chem 1996;271:4134-4137.

-49 Hsu MH, Wang M, Browning DD, Mukaida $\mathrm{N}$, Ye RD: NF- $\mathrm{BB}$ activation is required for C5a-induced interleukin-8 gene expression in mononuclear cells. Blood 1999;93:3241-3249.

50 Yang M, Sang H, Rahman A, Wu D, Malik $\mathrm{AB}$, Ye $\mathrm{RD}: \mathrm{G} \alpha_{16}$ couples chemoattractant receptors to NF- $\kappa \mathrm{B}$ activation. J Immuno 2001; 166:6885-6892.

51 Wong YH, Conklin BR, Bourne HR: $\mathrm{G}_{\mathrm{z}}$-mediated hormonal inhibition of cyclic AMP accumulation. Science 1992;255:339-342.

52 Liu AM, Wong YH: $\mathrm{G}_{16}$-mediated activation of nuclear factor $\mathrm{\kappa B}$ by the adenosine $\mathrm{A}_{1}$ receptor involves $\mathrm{c}$-Src, protein kinase $\mathrm{C}$, and ERK signaling. J Biol Chem 2004;279:5319653204 .

53 Qian NX, Russell M, Buhl AM, Johnson GL: Expression of GTPase-deficient $\mathrm{G}_{16}$ inhibits Swiss 3T3 cell growth. J Biol Chem 1994; 269:17417-17423.

54 Chan JS, Lee JW, Ho MK, Wong YH: Preactivation permits subsequent stimulation of phospholipase $\mathrm{C}$ by $\mathrm{G}_{\mathrm{i}}$-coupled receptors. Mol Pharmacol 2000;57:700-708.
55 Gaudreau R, Le Gouill C, Metaoui S, Lemire S, Stankova J, Rola-Pleszczynski M: Signalling through the leukotriene $\mathrm{B}_{4}$ receptor involves both $\alpha_{\mathrm{i}}$ and $\alpha_{16}$, but not $\alpha_{\mathrm{q}}$ or $\alpha_{11} \mathrm{G}$ protein subunits. Biochem J 1998;335:15-18.

56 Matsuoka M, Kaziro Y, Asano S, Ogata E: Analysis of the expression of seven $G$ protein $\alpha$ subunit genes in hematopoietic cells. Am J Med Sci 1993;306:89-93.

57 Marty C, Browning DD, Ye RD: Identification of tetratricopeptide repeat 1 as an adaptor protein that interacts with heterotrimeric $\mathrm{G}$ proteins and the small GTPase Ras. Mol Cell Biol 2003;23:3847-3858.

- 58 Sikorski RS, Boguski MS, Goebl M, Hieter P: A repeating amino acid motif in CDC23 defines a family of proteins and a new relationship among genes required for mitosis and RNA synthesis. Cell 1990;60:307-317.

59 Goebl M, Yanagida M: The TPR snap helix: a novel protein repeat motif from mitosis to transcription. Trends Biochem Sci 1991;16: 173-177.

60 Blatch GL, Lassle M: The tetratricopeptide repeat: a structural motif mediating proteinprotein interactions. Bioessays 1999;21:932939.

61 Dohlman HG, Thorner J: RGS proteins and signaling by heterotrimeric $G$ proteins. J Biol Chem 1997:272:3871-3874.

62 Day PW, Carman CV, Sterne-Marr R, Benovic JL, Wedegaertner PB: Differential interaction of GRK2 with members of the $\mathrm{G} \alpha_{\mathrm{q}}$ family. Biochemistry 2003;42:9176-9184.

63 Day PW, Tesmer JJ, Sterne-Marr R, Freeman LC, Benovic JL, Wedegaertner PB: Characterization of the GRK2 binding site of $\mathrm{G} \alpha_{\mathrm{q}}$. J Biol Chem 2004;279:53643-53652.

64 Schmidt A, Hall A: Guanine nucleotide exchange factors for Rho GTPases: turning on the switch. Genes Dev 2002;16:1587-1609.

65 Lutz S, Freichel-Blomquist A, Yang Y, Rumenapp U, Jakobs KH, Schmidt M, Wieland T: The guanine nucleotide exchange factor p63RhoGEF, a specific link between $\mathrm{G}_{\mathrm{q} / 11^{-}}$ coupled receptor signaling and RhoA. J Biol Chem 2005;280:11134-11139.

66 Rojas RJ, Yohe ME, Gershburg S, Kawano T, Kozasa T, Sondek J: $\mathrm{G} \alpha_{\mathrm{q}}$ directly activates p63RhoGEF and Trio via a conserved extension of the Dbl homology-associated pleckstrin homology domain. J Biol Chem 2007; 282:29201-29210

67 Tenailleau S, Corre I, Hermouet S: Specific expression of heterotrimeric $G$ proteins $G_{12}$ and $\mathrm{G}_{16}$ during human myeloid differentiation. Exp Hematol 1997;25:927-934.

68 Baltensperger K, Porzig H: The P2U purinoceptor obligatorily engages the heterotrimeric $\mathrm{G}$ protein $\mathrm{G}_{16}$ to mobilize intracellular $\mathrm{Ca}^{2+}$ in human erythroleukemia cells. J Biol Chem 1997;272:10151-10159.

69 Ghose S, Porzig H, Baltensperger K: Induction of erythroid differentiation by altered $\mathrm{G}_{16}$ activity as detected by a reporter gene assay in MB-02 cells. J Biol Chem 1999;274: 12848-12854. 
-70 Mapara MY, Bommert K, Bargou RC, Leng C, Beck C, Ludwig WD, Gierschik P, Dorken B: $G$ protein subunit $G \alpha_{16}$ expression is restricted to progenitor $\mathrm{B}$ cells during human B-cell differentiation. Blood 1995;85:18361842.

71 Wells TN, Power CA, Proudfoot AE: Definition, function and pathophysiological significance of chemokine receptors. Trends Pharmacol Sci 1998;19:376-380.

72 Tokoyoda K, Egawa T, Sugiyama T, Choi BI, Nagasawa T: Cellular niches controlling B lymphocyte behavior within bone marrow during development. Immunity 2004;20: 707-718.

73 Fedyk ER, Ryyan DH, Ritterman I, Springer TA: Maturation decreases responsiveness of human bone marrow B lineage cells to stromal-derived factor 1 (SDF-1). J Leukoc Biol 1999;66:667-673.

74 Lapidot T: Mechanism of human stem cell migration and repopulation of NOD/SCID and $\mathrm{B} 2 \mathrm{~m}$ null NOD/SCID mice. The role of SDF-1/CXCR4 interactions. Ann NY Acad Sci 2001;938:83-95.

75 Gershengorn MC, Geras-Raaka E, Varma A, Clark-Lewis I: Chemokines activate Kaposi's sarcoma-associated herpesvirus G-proteincoupled receptor in mammalian cells in culture. J Clin Invest 1998;102:1469-1472.

76 Rosenkilde MM, Kledal TN, Brauner-Osborne H, Schwartz TW: Agonists and inverse agonists for the herpesvirus 8-encoded constitutively active seven-transmembrane oncogene product, ORF-74. J Biol Chem 1999; 274:956-961.

77 Polson AG, Wang D, DeRisi J, Ganem D: Modulation of host gene expression by the constitutively active $G$ protein-coupled receptor of Kaposi's sarcoma-associated herpesvirus. Cancer Res 2002;62:4525-4530.

78 Munshi N, Ganju RK, Avraham S, Mesri EA, Groopman JE: Kaposi's sarcoma-associated herpesvirus-encoded G protein-coupled receptor activation of c-jun amino-terminal kinase/stress-activated protein kinase and lyn kinase is mediated by related adhesion focal tyrosine kinase/proline-rich tyrosine kinase 2. J Biol Chem 1999;274:3186331867.

-79 Bais C, Santomasso B, Coso O, Arvanitakis L, Raaka EG, Gutkind JS, Asch AS, Cesarman E, Gershengorn MC, Mesri EA: G-protein-coupled receptor of Kaposi's sarcomaassociated herpesvirus is a viral oncogene and angiogenesis activator. Nature 1998;391: 86-89.

80 Hempel WM, DeFranco AL: Expression of phospholipase C isozymes by murine B lymphocytes. J Immunol 1991;146:37133720.

81 Chou WC, Levy DE, Lee CK: STAT3 positively regulates an early step in B-cell development. Blood 2006;108:3005-3011.
82 Kabouridis PS, Waters ST, Escobar S, Stanners J, Tsoukas CD: Expression of GTP-binding protein $\alpha$ subunits in human thymocytes. Mol Cell Biochem 1995;144:45-51.

-83 Lippert E, Baltensperger K, Jacques Y, Hermouet $S: G \alpha_{16}$ protein expression is up- and down-regulated following T-cell activation: disruption of this regulation impairs activation-induced cell responses. FEBS Lett 1997; 417:292-296.

84 Stanners J, Kabouridis PS, McGuire KL, Tsoukas CD: Interaction between $\mathrm{G}$ proteins and tyrosine kinases upon $\mathrm{T}$ cell receptorCD3-mediated signaling. J Biol Chem 1995; 270:30635-30642.

85 Zhou J, Stanners J, Kabouridis P, Han H, Tsoukas CD: Inhibition of TCR/CD3-mediated signaling by a mutant of the hematopoietically expressed $\mathrm{G}_{16}$ GTP-binding protein. Eur J Immunol 1998;28:1645-1655.

86 Molon B, Gri G, Bettella M, Gomez-Mouton C, Lanzavecchia A, Martinez AC, Manes S, Viola A: T cell costimulation by chemokine receptors. Nat Immunol 2005;6:465-471.

87 Guex N, Peitsch MC: Swiss-Model and the Swiss-PdbViewer: an environment for comparative protein modeling. Electrophoresis 1997;18:2714-2723.

-88 Wall MA, Coleman DE, Lee E, Iniguez-Lluhi JA, Posner BA, Gilman AG, Sprang SR: The structure of the $G$ protein heterotrimer $\mathrm{G}_{\mathrm{i}} \alpha_{1} \beta_{1} \gamma_{2}$. Cell 1995;83:1047-1058.

89 Lambright DG, Sondek J, Bohm A, Skiba NP, Hamm HE, Sigler PB: The $2.0 \AA$ crystal structure of a heterotrimeric $\mathrm{G}$ protein. $\mathrm{Na}$ ture 1996;379:311-319.

90 Offermanns S, Negulescu P, Hu YH, Simon MI: Conditionally expressed $\mathrm{G} \alpha_{15}$ couples to endogenous receptors in GH3 cells. Naunyn Schmiedebergs Arch Pharmacol 2001;364: 140-148.

91 Martin RS, Reynen PH, Calixto JJ, Reyes CL, Chang TK, Dietrich PS, Bonhaus DW, MacLennan SJ: Pharmacological comparison of a recombinant $\mathrm{CB}_{1}$ cannabinoid receptor with its $\mathrm{G} \alpha_{16}$ fusion product. J Biomol Screen 2002; 7:281-289.

92 Amatruda TT 3rd, Gerard NP, Gerard C, Simon MI: Specific interactions of chemoattractant factor receptors with G-proteins. J Biol Chem 1993;268:10139-10144.

-93 Buhl AM, Eisfelder BJ, Worthen GS, Johnson GL, Russell M: Selective coupling of the human anaphylatoxin C5a receptor and $\alpha_{16}$ in human kidney 293 cells. FEBS Lett 1993;323: 132-134.

-94 Crass T, Ames RS, Sarau HM, Tornetta MA, Foley JJ, Kohl J, Klos A, Bautsch W: Chimeric receptors of the human $\mathrm{C} 3 \mathrm{a}$ receptor and C5a receptor (CD88). J Biol Chem 1999;274: 8367-8370.

95 Tian Y, Lee MM, Yung LY, Allen RA, Slocombe PM, Twomey BM, Wong YH: Differential involvement of $\mathrm{G} \alpha_{16}$ in CC chemokine-induced stimulation of phospholipase C $\beta$, ERK, and chemotaxis. Cell Signal 2008; 20:1179-1189.
-96 Kuang Y, Wu Y, Jiang H, Wu D: Selective G protein coupling by $\mathrm{C}-\mathrm{C}$ chemokine receptors. J Biol Chem 1996;271:3975-3978.

97 Wu D, LaRosa GJ, Simon MI: G proteincoupled signal transduction pathways for interleukin-8. Science 1993;261:101-103.

-98 Parmentier ML, Joly C, Restituito S, Bockaert J, Grau Y, Pin JP: The G protein-coupling profile of metabotropic glutamate receptors, as determined with exogenous $\mathrm{G}$ proteins, is independent of their ligand recognition domain. Mol Pharmacol 1998;53: 778-786.

-99 Zhu X, Birnbaumer L: G protein subunits and the stimulation of phospholipase $\mathrm{C}$ by $\mathrm{G}_{\mathrm{s}}$-and $\mathrm{G}_{\mathrm{i}}$-coupled receptors: lack of receptor selectivity of $\mathrm{G} \alpha_{16}$ and evidence for a synergic interaction between $G \beta \gamma$ and the $\alpha$ subunit of a receptor activated $\mathrm{G}$ protein. Proc Natl Acad Sci USA 1996;93:28272831.

100 Kotani M, Mollereau C, Detheux M, Le Poul E, Brezillon S, Vakili J, Mazarguil H, Vassart G, Zajac JM, Parmentier M: Functional characterization of a human receptor for neuropeptide FF and related peptides. Br J Pharmacol 2001;133:138-144.

101 Chambers JK, Macdonald LE, Sarau HM, Ames RS, Freeman K, Foley JJ, Zhu Y, McLaughlin MM, Murdock P, McMillan L, Trill J, Swift A, Aiyar N, Taylor P, Vawter L, Naheed S, Szekeres P, Hervieu G, Scott C, Watson JM, Murphy AJ, Duzic E, Klein C, Bergsma DJ, Wilson S, Livi GP: A G protein-coupled receptor for UDP-glucose. J Biol Chem 2000;275:10767-10771.

102 Ueda T, Ugawa S, Yamamura H, Imaizumi Y, Shimada S: Functional interaction between T2R taste receptors and G-protein $\alpha$ subunits expressed in taste receptor cells. J Neurosci 2003;23:7376-7380.

103 Nelson G, Hoon MA, Chandrashekar J, Zhang Y, Ryba NJ, Zuker CS: Mammalian sweet taste receptors. Cell 2001;106:381390.

104 Nelson G, Chandrashekar J, Hoon MA, Feng L, Zhao G, Ryba NJ, Zuker CS: An amino-acid taste receptor. Nature 2002; 416:199-202.

105 Riobo NA, Saucy B, Dilizio C, Manning DR: Activation of heterotrimeric G proteins by Smoothened. Proc Natl Acad Sci USA 2006;103:12607-12612.

106 Masdeu C, Faure H, Coulombe J, Schoenfelder A, Mann A, Brabet I, Pin JP, Traiffort E, Ruat M: Identification and characterization of Hedgehog modulator properties after functional coupling of smoothened to $\mathrm{G}_{15}$. Biochem Biophys Res Commun 2006; 349:471-479.

107 Wu D, Katz A, Lee CH, Simon MI: Activation of phospholipase $\mathrm{C}$ by $\alpha_{1}$-adrenergic receptors is mediated by the $\alpha$ subunits of $\mathrm{G}_{\mathrm{q}}$ family. J Biol Chem 1992;267:2579825802 . 